\title{
PELATIHAN KADER DALAM MELAKUKAN KONSELING SEDERHANA SEBAGAI DUKUNGAN SOSIAL UNTUK MENGELOLA POJOK CURHAT
}

\author{
Evin Novianti ${ }^{1}$, Diah Ratnawati ${ }^{2}$, Duma Lumban Tobing \\ ${ }^{1,2,3}$ Prodi Keperawatan, Universitas Pembangunan Nasional Veteran Jakarta \\ ${ }^{1}$ Surel:evinnovianti@upnvj.ac.id
}

\begin{abstract}
The elderly experience various conditions of decline both physically and psychologically, especially in the current Covid-19 condition, the elderly are isolated from the social environment. To assist the task of cadres to monitor the condition of the elderly, a counseling media is needed to help connect the elderly with their cadres. The purpose of implementing this community partnership program is to increase the knowledge of cadres about the physical and psychological health of the elderly during the pandemic and the ability of cadres to conduct simple counseling to the elderly. This program helps the elderly to prevent the deterioration of their physical and mental health conditions. The method of implementation is by socializing what kind of support health cadres should provide to the elderly, how to recognize the characteristics of the elderly who are mentally healthy and who are at risk of mental problems, and how cadres do simple counseling. The results of the training, cadres experienced a significant increase in knowledge with the highest emotional ability increased by 4.8 points $(p$-value $=0.001)$ followed by the ability to provide information 3.9 points ( $p$-value $=0.001)$, the instrument ability increased by 2.2 points $(p$-value $=0.001)$ and the award increased by 1.5 points ( $p$-value=0.001). Meanwhile, the ability to do simple counseling increased by 4 points with a p-value of 0.001. Increasing the ability of cadres to conduct counseling is beneficial for the health of the elderly in the future.
\end{abstract}

Keywords: social support, counseling, elderly, outpouring

\begin{abstract}
ABSTRAK
Lansia mengalami berbagai kondisi penurunan baik fisik maupun psikis, apalagi pada condisi covid-19 saat ini, lansia menjadi terisolasi dari lingkungan sosial. Untuk membantu tugas para kader memantau kondisi lansia, dibutuhkan suatu media konseling membantu menghubungkan lansia dengan kadernya. Tujuan pelaksanaan program kemitraan masyarakat ini adalah meningkatkan pengetahuan kader tentang kesehatan fisik dan psikologis lansia di masa pandemik dan kemampuan kader melakukan konseling sederhana kepada lansia. Program ini membantu lansia mencegah memburuknya kondisi fisik serta kesehatan jiwa lansia. Metode pelaksanaan adalah dengan sosialisasi tentang apa saja dukungan yang harus diberikan kader kesehatan kepada lansia, bagaimana mengenal ciri-ciri lansia dengan sehat jiwa dan yang berisiko terjadinya masalah kejiwaan, serta cara kader melakukan konseling sederhana. Hasil pelatihan, kader mengalami peningkatan pengetahuan secara signifikant dengan kemampuan emosional paling tinggi naik sebesar 4,8 poin ( $\mathrm{p}$-value=0,001) dikuti dengan kemampuan memberikan informasi 3,9 poin ( $p$-value $=0,001$ ), kemampuan instrumen naik 2,2 poin ( $p$-value $=0,001)$ dan penghargaan naik 1,5 poin $(p$-value $=0,001)$. Kemampuan melakukan konseling sederhana naik 4 poin dengan $p$ value 0,001 . Meningkatnya kemampuan kader melakukan konseling bermanfaat bagi kesehatan lansia di masa yang akan datang.
\end{abstract}

Kata Kunci: dukungan sosial, konseling, lansia, pojok curhat

\section{PENDAHULUAN}

Situasi saat ini menunjukkan setengah jumlah lansia di dunia (400 juta jiwa) berada di Asia, pertumbuhan lansia pada negara sedang berkembang lebih tinggi dari negara yang sudah berkembang dan masalah terbesar lansia adalah penyakit degeneratif. Diperkirakan pada tahun 2050 sekitar $75 \%$ lansia penderita penyakit degeneratif tidak dapat beraktifitas (tinggal di rumah) (Depkes, 2018). Hasil penelitian Riskesdas (2018) menunjukkan jumlah lansia di Indonesia sekitar 16,5 juta jiwa dari seluruh jumlah penduduk yang mencapai lebih dari 220 juta jiwa dan diperkirakan tahun 2025 meningkat empat kali lipatnya. 
Kondisi di atas sejalan dengan data statistik di Kecamatan Limo,Depok (2020), salah satu kecamatan di kota Depok, sebelah timur laut dengan ketinggian \pm 70 meter di atas permukaan air laut dengan jumlah Kelurahan di Kecamatan Limo sebanyak 4 kelurahan yaitu Meruyung, Grogol, Krukut dan Limo. Penduduk lansia di Kecamatan Limo pada rentang usia 55-59 tahun berjumlah 4.124 jiwa, 60-64 tahun berjumlah 2.556 jiwa, usia 65-69 adalah 1.665 jiwa, usia 7074 berjumlah 889 dan usia $>75$ tahun adalah 1.053 jiwa. Jumlah lansia yang terbilang besar, membutuhkan perhatian dan keterlibatan pengabdi dalam meningkatkan kesejahteraan kesehatan jiwa (Sumarmi \& Desmawati, 2015). Puskesmas yang ada di Kecamatan Depok ini hanya ada satu yang terletak di wilayah kecamatan Pancoran Mas berjarak sekitar 7-9 km dari kecamatan Limo, menyediakan poli lansia yang melayani berbagai keluhan fisik lansia, namun belum tersedia layanan kesehatan jiwa pada lansia.

Keluhan fisik terbanyak lansia di kecamatan Limo berdasarkan data dinas kota Depok tahun 2018 yaitu hipertensi 18,41\%, diabetes mellitus 11,24\&, katarak 10,95\% dan CKD 9,42\% sedangkan sisanya adalah stroke, dispepsia dan ISPA. Seiring bertambahnya Umur Harapan Hidup (UHH) maka keberadaan para lanjut usia tidak dapat diabaikan, sehingga perlu diupayakan peningkatan kualitas hidup bagi kelompok umur lanjut usia. Pelayanan kesehatan pra lansia dan lansia adalah penduduk usia 55 tahun ke atas yang mendapatkan pelayanan kesehatan sesuai standar yang dilakukan oleh tenaga kesehatan baik di puskesmas Grogol dan posyandu lansia yaitu Dahlia Senja di Kelurahan Limo.

Kegiatan yang diadakan di Dahlia Senja sesungguhnya sudah banyak, hanya saja belum ada kegiatan khusus untuk pelayanan kesehatan holistik dan komplementer. Ditambah lagi dalam kondisi pandemic kegiatan menjadi terbatas pelaksanaannya. Kegiatan Posbindu selama ini hanya seputar pemeriksaan fisik dan pengobatan belum mengarah pada kesehatan jiwa lansia serta pendidikan kesehatan untuk lansia terkait masalah kesehatan secara terpadu antara fisik, mental, dan spiritual jarang dilakukan.

Kondisi pandemik menambah sulitnya lansia bergerak secara sosial untuk sekedar bercerita dengan sesamanya. Namun, kemampuan kader seperti ini, lansia dengan segala keterbatasannya, dapat menceritakan dan mendapatkan solusi akan masalah yang dihadapi baik secara fisik, psikososial, dan spiritual kepada kader setempat. Mempertimbangkan jumlah lansia yang banyak sedangkan jumlah kader pada Kecamatan Limo belum mencapai perbandingan 1:20, maka untuk membantu jalannya kegiatan kader, dibutuhkan beberapa upaya promotif yang dapat menjangkau lansia di masa pandemi ini.

Lansia dengan proses penyakit yang bersifat progresif secara tak langsung berdampak pada kesehatan jiwanya ditambah lagi jika tidak adanya dukungan sosial. Masalah kesehatan jiwa yang dapat mucul pada lansia adalah kecemasan, depresif, psikotik akut dan gangguan mental organik. Lansia dengan keterbatasan ruang dan geraknya, membuat lansia tidak dapat menyelesaikan masalah hidupnya dengan efektif, tidak ada teman bicara yang dapat jadi ventilasi untuk lansia (W et al., 2018)

Hasil wawancara yang dilakukan dengan kader Posbindu Dahlia Senja pada bulan Maret 2021 didapatkan sudatu kondisi dimana lansia di hari tuanya merasa dibebankan tugas dan tanggung jawab lain seperti mengurus cucu, memasak, bahkan ada lansia ditempatkan oleh keluarganya di ruangan kecil dari rumah. Lansia dengan penyakit kronis karena pola hidup yang tidak sehat dan kurang manajemen stress membuat lansia merasakan tidak bahagia di hari tuanya. Lansia bahkan merasa malu jika harus menceritakan keluh kesahnya ke orang lain. Kader Kesehatan sendiripun merasakan tidak punya kemampuan untuk menjadi tempat curhat para lansia. Pengalaman kader selama ini melakukan kunjungan rumah hanya sebatas fisik saja, belum sampai kepada mendengarkan keluh kesah lansia. Oleh karena itu, pengabdian masyarakat ini dilakukan dalam dua tahapan. Tahap pertama yang telah dilakukan oleh pengabdi adalah memperkuat pondasi kemampuan kader untuk dapat menggali masalah psikologis lansia serta memberikan dukungan 
sosial kepada lansia. Tahap kedua adalah pengembangan curhat berbasis aplikasi. Kader Kesehatan didampingi oleh pengabdi masyarakat dalam menjalankan pojok curhat lansia ini. Tim yang ada didalamnya adalah tim dari kesehatn jiwa, tim kesehatan keluarga dan tim kesehatan fisik lansia.

Pengabdian masyarakat ini dilakukan melalui kemitraan dengan Direktorat Jendral/ Ditjen Kementrian Pemberdayaan Perempuan dan Anak/PPA, Posyandu Dahlia Senja, dan pihak Kelurahan Limo yang berada di Kecamatan Limo Kota Depok. Pojok Curhat dibentuk untuk menjawab kebutuhan lansia dalam menyalurkan perasaan kepada kader dan tim ahli dari dosen UPN Veteran Jakarta. Kegiatan pelatihan kader untuk konseling pojok curhat sebagai langkah awal untuk menuju lansia sehat.

\section{Dukungan sosial}

Dukungan sosial adalah informasi dari orang yang dicintai atau memiliki arti penting bagi individu yang sedang mengalami masalah atau sakit (Nuggroho et al., 2017). Sumber dukungan sosial dapat tumbuh dari kelompok yang memiliki kesamaan minat, kesamaan akitivitas, senasib dan sepenanggungan. Dari kelompoknya tersebut,lansia beraktifitas sesuai dengan harapannya, mendapatkan respon positif, saling memberikan semangat dan persetujuan pendapat yang dapat meningkatkan harga diri lansia. Bentuk dukungan sosial yang dibutuhkan lansia adalah dukungan emosi, penghargaan, informasi dan instrumental. Kebutuhan material berupa sandang dan pangan ataupun kebutuhan lain yang dibutuhkan lanisa seperti pampers. Melalui kunjungan rumah, kader dahlia senja telah melakukan rutinintas ini, menyalurkan bantuan dari donatur kepada para lansia. Dukungan informasi berupa memberikan informasi mengenai pengetahuan akan proses penyembuhan penyakit. Pada kondisi pandemi saat ini, memberikan pengetahuan kepada lansia tentang adaptasi kebiasaan baru. Dukungan emosional berupa perhatian, kasih sayang, empati, bersedia mendengar keluh kesah dan menunjukkan sikap percaya pada apa yang lansia rasakan. Dukungan penghargaan adalah penilaian positif yang diberikan terhadap aspek positif yang masih dimiliki oleh lansia (Khoirunnisa et al., 2017).

\section{METODE PELAKSANAAN PKM}

Metode pelaksanaan kegiatan program kemitraan masyarakat dimulai dengan sosialisasi program. Karena kondisi di masa pandemik dan adanya Pembatasan Pergerakan Kegiatan Masyarakat (PPKM), maka sosialisasi dukungan sosial kader dan pengetahuan akan kesehatan jiwa lansia diberikan secara daring. Kegiatan dilakukan dengan diskusi pada platform zoom dalam dua pertemuan. Pada pertemuan pertama tanggal 24 Agustus 2021 digali terlebih dahulu pengalaman kader dalam merawat lansia serta kesulitan yang dialami selama PPKM. Sebelum diberikan materi pelatihan, kader mengisi formulir pre test melalui google form. Setelah pertemuan pertama, kader diminta untuk melaksanakan konseling sederhana kepada lansia melalui video call. Pertemuan kedua dilakukan pada tanggal 31 Agustus 2021 untuk mengevaluasi pelaksanaan konseling sederhana yang telah dilakukan kader. Setelah evaluasi, kader diminta mengisi kembali formulir post test.

Terdapat dua kuisioner yang digunakan untuk mengukur kemampuan kader dalam melakukan dukungan sosial, yang didalamnya berisi tentang dukungan emosi, penghargaan, informasi dan instrumental. Kuisioner kedua adalah untuk mengukur kemampuan kader melakukan konseling sederhana. Kedua kuisioner ini telah digunakan pada penelitian sebelumnya dan diuji validitas dengan nilai reliabel $=0,917$ (Ratnawati et al., 2019). Variable kemampuan kader melakukan dukungan sosial dianalisis dan kemampuan melakukan konseling sederhana pre dan post without control group menggunakan uji analisis paired t-test dengan distribusi normal. 


\section{HASIL DAN PEMBAHASAN}

Berikut disampaikan hasil distribusi karakteristik kader meliputi usia dan pengalaman menjadi kader di Posbindu Dahlia Senja Kelurahan Limo, Depok.

Tabel 1. Distribusi karakteristik kader berdasarkan usia dan pengalaman menjadi kader $(\mathrm{n}=20)$

\begin{tabular}{lccccc}
\hline & Mean & Median & Sd & Min & Max \\
\hline Usia & 53,34 & 43 & 6,31 & 38 & 67 \\
\hline $\begin{array}{l}\text { Pengalaman jadi } \\
\text { kader (tahun) }\end{array}$ & 4,45 & 4 & 4,11 & 1 & 13 \\
\hline
\end{tabular}

Tabel 1. Menunjukkan bahwa rata-rata kader berusia 53 tahun dan terdapat perbedaan yang bervariasi dengan standard deviasi 6,32, usia kader termuda adalah 38 tahun dan tertua adalah 67 tahun. Untuk pengalaman menjadi kader, rata-rata 4 tahun dengan perbedaan pengalaman yang bervariasi yaitu 1 tahun dan paling berpengalaman 13 tahun. Terdapat 6 orang dengan pengalaman menjadi kader di atas 5 tahun (30\%), hal ini menjadi faktor kekuatan bagi Kelurahan Limo untuk membina kader yang baru bergabung, untuk terus berupaya melakukan deteksi dini gangguan jiwa di masyarakat. Kekuatan berupa lama menjadi kader adalah salah satu faktor penting yang mempengaruhi peningkatan kapasitas kader selama pelatihan (Witdiawati, et al., 2018).

Tabel 2. Karakteristik Kader Berdasarkan Pendidikan Terakhir Kader (n=20)

\begin{tabular}{|c|c|c|}
\hline Tingkat pendidikan & Frekuensi & Persentase (\%) \\
\hline a. SD & 3 & 15 \\
\hline b. SMP & 6 & 20 \\
\hline c. SMA & 8 & 26 \\
\hline d. PT & 3 & 10 \\
\hline Jumlah & 20 & 100 \\
\hline
\end{tabular}

Berdasarkan Tabel 2 menjelaskan karakteristik kader dilihat dari jenjang pendidikan terakhir, terlihat bahwa pendidikan terakhir SMP dan SMA memiliki proporsi yang hampir sama, sedangkan yang tidak sekolah dan berpendidikan SD hanya 3 orang (15\%), namun secara keseluruhan, kader dapat membaca dan menulis, hal ini menjadi salah satu faktor kekuatan bagi kelurahan Limo. Selain itu, untuk pekerjaan kader, $100 \%$ adalah ibu rumah tangga. Para kader di Dahlia Senja terbilang sangat aktif mengikuti kegiatan-kegiatan untuk mensejahterakan kesehatan lansia, hanya saja di kondisi PPKM saat ini, lebih pasif dibandingkan kegiatan sebelum kejadian pandemik covid-19.

Tingkat pendidikan bervariasi, terbesar berada di SMA dan SMP, namun perbedaan tingkat pendidikan tidak mengurangi semangat yang ada untuk melakukan pengabdian kepada masyarakat. Uraian tersebut ditegaskan oleh Sumarni et al. (2019) bahwa faktor pendidikan mendukung peningkatan pengetahuan maupun keterampilan kader setelah dilakukan pelatihan. Pelatihan yang diberikan oleh pengabdi, mampu diterima dengan baik dan para kader mengatakan ingin menambah terus pengalaman yang diberikan para pengabdi. Hal ini merupakan faktor positif yang dapat dikembangkan untuk tercapainya pojok curhat lansia. 


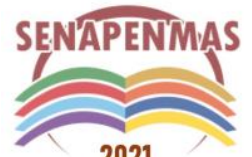

2021
Seminar Nasional Hasil Penelitian dan Pengabdian Kepada Masyarakat 2021 Pengembangan Ekonomi Bangsa Melalui Inovasi Digital Hasil Penelitian dan Pengabdian Kepada Masyarakat Jakarta, 21 Oktober 2021

Tabel 3. Analisis kemampuan kader memberikan dukungan sosial sebelum dan sesudah diberikan pelatihan $(n=20)$

\begin{tabular}{|c|c|c|c|c|c|c|}
\hline \multicolumn{2}{|c|}{ Variabel } & Mean & SD & $\mathrm{t}$ & $95 \% \mathrm{CI}$ & P-value \\
\hline \multirow{3}{*}{$\begin{array}{l}\text { Dukungan } \\
\text { emosional }\end{array}$} & Pre & 23,20 & 3,548 & $-4,951$ & $-6,829 ;-2,771$ & \multirow{3}{*}{0,001} \\
\hline & Post & 28,00 & 1,892 & & & \\
\hline & Selisih & 4,80 & 1,65 & & & \\
\hline \multirow{3}{*}{$\begin{array}{l}\text { Dukungan } \\
\text { penghargaan }\end{array}$} & Pre & 16,10 & 0,788 & \multirow[t]{3}{*}{$-5,252$} & $-2,098 ;-0,902$ & \multirow{3}{*}{0,001} \\
\hline & Post & 17,60 & 1,353 & & & \\
\hline & Selisih & 1,50 & 0,565 & & & \\
\hline \multirow{3}{*}{$\begin{array}{l}\text { Dukungan } \\
\text { informasi }\end{array}$} & Pre & 16,55 & 1,761 & \multirow[t]{3}{*}{$-7,391$} & $-5,004 ;-2,796$ & \multirow{3}{*}{0,001} \\
\hline & Post & 20,45 & 1,234 & & & \\
\hline & Selisih & 3,90 & 0,527 & & & \\
\hline \multirow{3}{*}{$\begin{array}{l}\text { Dukungan } \\
\text { instrumental }\end{array}$} & Pre & 15,90 & 1,410 & \multirow[t]{3}{*}{$-5,311$} & $-3,067 ;-1,333$ & \multirow{3}{*}{0,001} \\
\hline & Post & 18,10 & 2,222 & & & \\
\hline & Selisih & 2,20 & 0,812 & & & \\
\hline
\end{tabular}

Dari tabel 3 di atas, terlihat bahwa pelatihan yang dilatih kepada kader dalam memberikan dukungan sosial baik emosional, penghargaan, informasi dan instrumental berpengaruh secara signifikant dengan nilai p-value 0,001 $(<0,005)$. Rata-rata kenaikan terbesar sebelum dan sesudah diberikan pelatihan adalah dukungan emosional, diikuti dengan dukungan informasi, dukungan instrumental dan dukungan penghargaan.

Dukungan sosial yang diberikan kader terdiri dari dukungan emosional, dukungan penghargaan, dukungan informasi dan dukungan instrumental (Rantepadang, 2012). Kader kesehatan di Posbindu Dahlia senja sudah mampu memberikan informasi berupa penyuluhan kesehatan sehingga tercapai dukungan sosial kader. Hasil dukungan informasional kader yang berpengaruh positif tersebut sesuai dengan penelitian dalam Setyoadi et al. (2013). Dukungan terbesar yang diberikan adalah dukungan emosional karena para kader sudah menjalani proses home visite sebelum terjadi covid-19, sehingga sudah ada kedekatan hubungan dengan para lansia dan tidak adanya kader baru disini. Dalam memberikan dukungan emosional, kader harus menanyakan bagaimana kondisi lansia, bagaimana perasaan lansia dengan kondisinya dan bagaimana selama ini lansia mengatasi masalah, maka dibutuhkan suatu kerja sama dengan care giver agar lansia dapat mencurahkan perasaannya terkait dengan penyakitnya (Novianti et al., 2020).

Adanya dukungan sosial kader terhadap lansia, diharapkan dapat menurunkan memburuknya kondisi kesehatan lansia serta meningkatkan deteksi dini terhadap kesehatan lansia baik fisik maupun mental. Peran kader disini sebagai pendamping lansia dan keluarga terutama di masa PPKM covid-19 sekarang ini, lansia mengalami keterisolasian dari dunia luar. Untuk menjembatani komunikasi dengan kader, pojok curhat lansia ini menjadi solusi yang tepat. Dengan kunjungan kader yang dapat dilakukan secara online, lansia dan keluarga mendapatkan informasi akan sakitnya. Seperti ditegaskan dalam penelitian Cahya et al. (2017) bahwa dukungan sosial dipengaruhi faktor pendorong yaitu petugas dan kader kesehatan dalam menjaga kesehatan lansia.

Pelaksanaan pojok curhat untuk lansia memberikan makna yang mendalam bagi kader, dimana mereka dapat dengan aktif mengetahui kondisi lansia tanpa takut tertular dan tidak menularkan virus covid-19 ke lansia. Dukungan informasipun juga telah baik diberikan kepada kader, kader telah dapat memberikan informasi terkait dengan kesehatan fisik lansia. Perlu ditambahkan adalah menggali kesehatan jiwa lansia sebagai dampak dari sakit fisik. Kader dilatih manajemen stress yang akan dilatih juga kepada lansia untuk mengurangi faktor stress (Setyoadi et al., 2013). 
Tabel 4. Analisis kemampuan kader melakukan konseling sederhana sebelum dan sesudah diberikan pelatihan $(n=20)$

\begin{tabular}{llllccc}
\hline \multicolumn{1}{c}{ Variabel } & & Mean & SD & t & 95\% CI & P-value \\
\hline $\begin{array}{lllllll}\text { Kemampuan } \\
\text { konseling }\end{array}$ & Pre & 12,35 & 2,540 & & & \\
\cline { 2 - 4 } Sederhana & Post & 16,35 & 1,348 & $-7,503$ & $-5,116 ;-2,884$ & 0,001 \\
\cline { 2 - 5 } & Selisih & 4,00 & 1.192 & & & \\
\hline
\end{tabular}

Tabel 4 menganalisis variable dependent konseling sederhana sebelum dan sesudah pelatihan, menggunakan uji analisis paired t-test karena data berdistribusi normal. Table 4 dianalisis bahwa adanya kenaikan kemampuan melakukan konseling sederhana secara signifikan dengan nilai pvalue $<0,005$ (95\% CI -5,116;-2,884). Kenaikan sebelum dan sesudah diberikan pelatihan sebesar 4 point.

Kader kesehatan membutuhkan penyegaran kembali bagaimana melakukan konseling sederhana kepada lansia, sehingga pelayanan yang diberikan dapat maksimal. Adapun materi yang diberikan kepada kader adalah proses memberikan konseling mulai salam, isi materi sampai penutup. Pengabdi terlebih dahulu memberikan demonstrasi dan diikuti oleh kader. Pola ini mengikuti proses pembentukan perilaku baru dengan metode redemontrasi (Yuniati Faiza, 2014). Kemampuan konseling yang paling mudah dirasakan oleh para kader adalah proses memberikan salam, anjuran kesehatan kepada lansia, karena sudah terbiasa dikerjakan sehari-harinya ketika melakukan home visite. Namun, kader belum sepenuhnya memahami bahwa sakit fisik dapat menyebabkan terjadinya masalah kejiwaan dan faktor kesepian lansia dapat menjadi pemicu munculnya atau sulit sembuhnya suatu penyakit (Putri \& Utami, 2017). Oleh karena itu, kader harus meningkatkan kemapuan dalam memberikan dukungan emosional terkait aspek psikologis dengan pelatihan untuk meningkatkan wawasan dan pengetahuan mengenai kondisi psikologis lansia di kalangan kader kesehatan agar dapat memberikan penanganan psikologis yang baik dan tepat bagi lansia (Sari, 2017). Hal tersebut dapat tercapai dengan pelatihan konseling sederhana yang aktif diikuti para kader. Pentingnya kemampuan kader dalam memberikan pengetahuan dan pendidikan kesehatan kepada lansia dan keluarga harus didasari memiliki ilmu dan pengalaman yang diperoleh dari pelatihan kader (Zakir, 2014).

Tabel 5. Kemampuan kader di Kelurahan Limo,Depok $(\mathrm{n}=20)$

\begin{tabular}{lcccc}
\hline \multicolumn{1}{c}{ Variabel } & & & Frekuensi & Persentase \\
\hline \multirow{3}{*}{ Dukungan sosial } & Pre & Tinggi & 8 & 40 \\
\cline { 2 - 5 } & & Rendah & 12 & 60 \\
\cline { 2 - 5 } & Post & Tinggi & 13 & 65 \\
\cline { 2 - 5 } & & Rendah & 7 & 35 \\
\hline \multirow{3}{*}{$\begin{array}{l}\text { Kemampuan konseling } \\
\text { sederhana }\end{array}$} & \multirow{2}{*}{ Pre } & Tinggi & 9 & 45 \\
\cline { 2 - 4 } & & Rendah & 11 & 55 \\
\cline { 2 - 5 } & Post & Tinggi & 14 & 70 \\
\cline { 3 - 5 } & & Rendah & 6 & 30 \\
\hline
\end{tabular}

Apabila kemampuan dukungan sosial dan kemampuan melakukan konseling dikategorikan menjadi tinggi dan rendah, maka terlihat pada tabel 5 bahwa kemampuan kader melakukan dukungan sosial sebelum diberikan pelatihan mayoritas kemampuan rendah $(60 \%)$ namun setelah diberikan pelatihan naik 25\% dengan mayoritas kemampuan tinggi 65\%. Kemampuan kader melakukan konseling sederhana kepada lansia sebelum diberikan pelatihan mayoritas adalah rendah $55 \%$ dan setelah diberikan pelatihan naik sebesar $25 \%$ menjadi mayoritas tinggi. 


\section{KESIMPULAN DAN SARAN}

\section{Kesimpulan}

Kegiatan pengabdian masyarakat ini sudah menjawab permasalahan penguatan kader dalam melakukan dukungan sosial dan konseling sederhana kepada lansia. Kegiatan ini sudah dirasakan bermanfaat bagi kader, walaupun belum banyak dirasakan oleh lansia. Namun, pengabdian masyarakat ini memiliki keberlanjutan program, dengan membentuk forum kerja sama dengan kelurahan Limo, sepakat untuk menciptakan desa ramah lansia, dimana lansia dapat cerita dengan leluasa kepada kader Dahlia Senja didampingi oleh dosen dari Fakultas Ilmu Keperawatan UPN Veteran Jakarta sesuai permasalahan lansia.

\section{Saran}

Peran dan tugas kader diterapkan dengan baik sehingga tercapainya masyarakat yang sadar akan kesehatan jiwa. Peran tersebut seperti melakukan dukungan sosial baik emosional, penghargaan, informasi dan instrumental terhadap kebutuhan kesehatan lansia baik fisik maupun mental. Dengan demikian kader dapat melaporkan kepada Puskesmas untuk melakukan rujukan jika kondisi lansia mengalami penurunan. Tindak lanjut berikutnya adalah pembentukan kelompok pendukung Pojok Curhat Lansia yang dilatih untuk menggunakan aplikasi lain seperti android, sms gateway, maupun website dan dilatih kemampuan dalam konseling maupun terapi yang dapat memberikan solusi bagi masalah lansia di Kelurahan Limo Depok. Untuk mewujudkan ini, untuk selanjutnya tim pengabdi menjalin MOU dengan Kelurahan Grogol untuk sepakat menciptakan Desa Ramah Lansia.

\section{Ucapan Terima Kasih}

Ucapan terima kasih kepada Kelompok lansia yang tergabung di dalam Dahlia Senja Kelurahan Limo Depok, telah memberikan kesempatan waktu dan tempat untuk berbagi ilmu dalam melatih lansia untuk aktif dan produktif di hari tuanya sehingga dapat meningkatkan kualitas hidup lansia. Produk yang dihasilkan semoga dapat bermanfaat bagi diri lansia, keluarga, kader dan masyarakat.

\section{REFERENSI}

Cahya, E., Harnida, H., \& Indrianita, V. (2017). Hubungan Dukungan Sosial Dengan Kualitas Hidup Lansia Di Posyandu Lansia Wiguna Karya Kebonsari Surabaya. Jurnal Keprawatan Dan Kebidanan, 0231, 36.

Khoirunnisa, N., Maliya, A., \& Handoyo, D. (2017). Hubungan antara dukungan sosial dengan keaktifan lansia dalam kegiatan posyandu lansia aisyiah di desa Pakisan Cawas Klaten. Naskah Publikasi Skripsi.

Novianti, E., Tobing, D. L., Wibisono, B., Kesehatan, F. I., Nasional, U. P., Jati, P., \& Selatan, K. J. (2020). Promotive and Preventive Efforts for Mental Health Through Web-Based Detection Early. Jurnal Keperawatan Jiwa, 8(1), 1-6.

Nuggroho, M. T., Putri, R. S. M., \& Dewi, N. (2017). HUBUNGAN KEAKTIFAN KADER DENGAN KUNJUNGAN LANSIA DI POSYANDU LANSIA PERMADI TLOGO SURYO MALANG Miko Tri Nuggroho 1), Rona Sari Mahaji Putri 2), Novita Dewi 3). Nursing News, 2(1), 247-255.

Putri, A. A., \& Utami, S. (2017). MENGIKUTI PROGRAM POSYANDU LANSIA DI WILAYAH KERJA PUSKESMAS AMBULU KABUPATEN JEMBER TAHUN 2016. 34, 1-11.

Ratnawati, D., Wahyudi, C. T., \& Zetira, G. (2019). Dukungan Keluarga Berpengaruh Kualitas Hidup Pada Lansia dengan Diagnosa Diabetes Melitus. Jurnal Ilmiah Ilmu Keperawatan Indonesia, 9(02), 585-593. https://doi.org/10.33221/jiiki.v9i02.229

Sari, N. (2017). Psikoedukasi Perkembangan Lansia Kepada Kader Puskesmas. Psikoislamedia: 
Jurnal Psikologi, 1(2), 267-278. https://doi.org/10.22373/psikoislamedia.v1i2.914

Setyoadi, S., Ahsan, A., \& Abidin, A. (2013). Hubungan Peran Kader Kesehatan Dengan Tingkat Kualitas Hidup Lanjut Usia. Jurnal Ilmu Keperawatan, 1(2), pp.183-192.

Sumarmi, \& Desmawati, L. (2015). Peran Kader Posyandu Sebagai Agen Pembaru Bagi Lansia di Dukuh Rejosari Kelurahan Ngijo Kecamatan Gunungpati Kota Semarang. Journal of Non Formal Eduvation and Community Empowerment: Semarang State University, IV(6), $15-25$.

Sumarni, S., Sutomo, A. H., Tursina, C., Purwanta, P., Wahdini, A. I., \& Kusumaningrum, N. (2019). Pengaruh pelatihan kader yandu lansia dalam menciptakan desa ramah dan sehat lansia di Desa Purwobinangun, Sleman. Journal of Community Empowerment for Health, 2(2), 110-119. https://doi.org/10.22146/jcoemph.41273

W, W., S, S., \& Mamuroh, L. (2018). Penguatan Kapasitas Kader Kesehatan dalam Upaya Meningkatkan Dukungan Sosial Berbasis Masyarakat terhadap Klien Kanker Payudara. Media Karya Kesehatan, 1(1), 1-10. https://doi.org/10.24198/mkk.v1i1.16983

Yuniati Faiza, D. Y. (2014). Pemanfaatan Posyandu Lanjut Usia. Jurnal Kesehatan Politeknik Kesehatan Palembang, $\quad 1, \quad 30-33$. https://jurnal.poltekkespalembang.ac.id/index.php/JPP/article/download/170/133

Zakir, M. (2014). Faktor-Faktor Yang Berhubungan Dengan Pemanfaatan Posyandu Lansia Kencana. Jurnal Ilmiah Keperawatan Sai Betik, 10(1), 64-69. 